\title{
STUDENT'S PARTICIPATION IN UPPER SECONDARY SCHOOL MANAGEMENT: APPROACHES TO THE REALITY OF THE SCHOOL SYSTEM IN THE STATE OF AMAZONAS
}

\section{PARTICIPAÇÃO ESTUDANTIL NA GESTÃO ESCOLAR DO ENSINO MÉDIO: APROXIMAÇÕES COM A REALIDADE DA REDE ESTADUAL DO AMAZONAS}

\section{PARTICIPACIÓN ESTUDIANTIL EN LA GESTIÓN DE LA ESCUELA SECUNDARIA: ENFOQUES DE LA REALIDAD DE LA RED ESTATAL DE AMAZONAS}

\begin{abstract}
This study discusses upper secondary school student's participation in educational management by presenting the results of a research conducted at a public school in the state of Amazonas, Brazil. Its purpose was to identify institutional actions that enable upper secondary school students' participation in educational management processes, assessing to what extent the principle of democratic management in public education has been made possible in these institutions. In this qualitative research the document analysis of school documents such as: Minutes, Pedagogic Political Project, Internal Regulations, Reports, and Manuals was performed. The findings indicate few and frail forms of student participation in secondary school management. An effort to mark democratic management as a principle in school documents exists, however there is a lack of propositions that enables student participation in secondary school management.
\end{abstract}

Keywords: Democratic Management. Student participation. Upper Secondary School

Resumo: Discute a participação de estudantes do ensino médio na gestão escolar, apresentando resultados de pesquisa realizada em uma escola pública do Estado do Amazonas. Objetivou identificar ações institucionais que viabilizam a participação de estudantes do ensino médio nos processos de gestão, verificando em que medida o princípio da gestão democrática do ensino público vem se materializando nas escolas de ensino médio. A metodologia tem perspectiva qualitativa aplicando a técnica da análise documental, contemplando documentos escolares, tais como: Atas, Projeto Político Pedagógico, Regimento Interno, Relatórios e Manuais. Os resultados

\footnotetext{
${ }^{1}$ Federal University of Amazonas. Manaus, Amazonas, Brazil.

${ }^{2}$ Municipal Office of Education. Manaus, Amazonas, Brazil.
} 
apontam poucas e frágeis formas de participação estudantil na gestão escolar do ensino médio. Há um esforço de demarcar a gestão democrática como princípio nos documentos escolares, mas faltam propostas que viabilizem a participação estudantil nas ações da gestão do ensino médio.

Palavras-chave: Gestão Democrática. Participação estudantil. Ensino Médio.

Resumen: Discuta la participación de estudiantes de secundaria en la gestión escolar, presentando los resultados de la investigación realizada en una escuela pública en el estado de Amazonas. Su objetivo era identificar acciones institucionales que permitan la participación de estudiantes de secundaria en los procesos de gestión, verificando hasta qué punto el principio de gestión democrática de la educación pública se ha materializado en las escuelas secundarias. La metodología tiene una perspectiva cualitativa que aplica la técnica de análisis de documentos, incluidos documentos escolares como: Actas, Proyecto político pedagógico, Reglas internas, Informes y Manuales. Los resultados muestran pocas y frágiles formas de participación estudiantil en la gestión de la escuela secundaria. Hay un esfuerzo por demarcar la gestión democrática como principio en los documentos escolares, pero no hay propuestas para garantizar una participación efectiva de los estudiantes en las acciones de gestión de la escuela secundaria.

Palabras clave: Gestión Democrática. Participación Estudiantil. Enseñanza Media.

\section{INTRODUCTION}

This article discusses student participation in educational management in the sphere of upper secondary education, based on the results of research conducted in a state school, located in Manaus, the capital city of Amazonas, Brazil. Its objective was to identify institutional assumptions and actions aimed at student participation in school management processes.

In this study, democratic management and student status as a subject, which are themes of major interest in the research field of Education are revisited. Verifying to what extent these two ideas, which are vital for public education of socially referenced quality, have been materializing in actions in upper secondary schools, and how they can strengthen each other was considered relevant.

The confluence between the two categories (democratic management in basic education and student status as a subject) gave rise to the object of study that deals with student participation in educational management processes. Student participation here is understood as a principle of democratic management and it is regarded both in its operational dimension, represented by the presence of students in decision-making spaces, and in its political dimension, which occurs when this group participates in decision-making processes and when actions of participation have the broadest process of society democratization as their horizon. (SOUZA, 2019; SPOSITO, 2001). 
Upper secondary education is the last stage of Brazilian basic education, and it is intended for individuals aged between 15 and 17 years old and all of those who have not completed this step within the expected age. As a result, upper secondary school audience consists of teenagers and young people, who seemingly have expertise regarding the school dynamics that cannot be ignored, in addition to the accumulation of other skills acquired in different dimensions of social life. As a pedagogical premise, one tends to expect that the trajectories of this audience are addressed as well as their position as individuals that able to participate in decisions concerning their school education path.

In the context of a democratic school management, student voices and projects must have a place in different institutional channels of participation, and can take a direct form, as in general assemblies and meetings, or representative form, through collegiate bodies. Studies on youth, however, indicate that youth protagonism is something yet to be achieved, within the imposed student status. (DAYRELL, 2007; DAYRELL; CARRANO, 2014).

Part of the alleged low student participation is explained by the lack of effective communication between school and youth cultures, and it is reflected in the obstacles that institutions find in acknowledging forms of student participation that diverge from the preestablished molds found in operating rules, school manuals and due to the constant refusal of youth groups to adjust to traditional models of participation.

The performance of young people in their school educational process may not correspond to the educational institution's idea of a student. It is the teenager's task trying to adapt and live in a turmoil that encompasses school world, youth world, real world. [...] The idea of time is not the same for schools and for youth participation. A divide is placed. (MARTINS; DAYRELL, 2013, p. 1271).

Seeking to learn to what degree student participation in educational management has happened and how it has been encouraged in upper secondary schools, the study examined the experience of a public state school in the state of Amazonas, Brazil, based on the following guiding questions: 1) What kinds of student participation in school management are established in the institution's pedagogic political project? 2) What are the main actions of student participation in educational management? 3) To what degree are the planned forms of participation connected to the participation practices documented in school?

Many of the public policies intended for the youth segment are designed and executed without the participation of students. In schools, a place in which public education policies happen, it is common to confirm the inexpressive participation of young students. 
It is a school disposition not considering a young person a valid interlocutor when important decisions for the school institution are made. Often, teenagers are not invited to express opinions and intervene even in matters that concern them directly. And this can surely be considered discouraging to participation and protagonism. (DAYRELL; CARRANO, 2014, p. 106).

In research undertaken in Manaus' public schools, Pinheiro and Caldas (2009) concluded that community participation in school management actions, student's participation included, is still modest and restricted to specific moments such as bimonthly parent-teacher conferences and cultural activities.

This study intended to verify to what extent the youth protagonism discourse found objective support points for settling at school, especially in educational management. From the experiences of the studied school setting, general elements can be extracted to analyze the situation and the challenges of student participation in upper secondary school management.

Through qualitative approach, this research seeks to understand student participation in educational management as a product of the relationship between what is instituted and the instituting management processes, including the discrepancies between what is stated in the documents that institutionalize student participation and the effective participation practices found in upper secondary schools. According to Minayo (1994), this type of research allows the understanding of singularities that can complete generalizations operated by statistical indicators.

The study correlates to previous academic knowledge produced in the area of Education on this topic and focuses on the experiences of student participation collected by a state school in Amazonas from 2013 to 2016. To preserve the institution's anonymity, the name "Amazonas School" will be used to refer to the research field.

At the chosen school, documents containing records on student participation in educational management practices were collected. School Council and pedagogical meetings minutes, pedagogic political projects, internal regulations, class representative reports, parents and students' procedures guidelines, and student president responsibilities were considered.

Documents are considered by Lüdke and André (1986, p. 39) as "powerful sources from which evidence that can support the researcher's claims and statements" can be elicited. The authors also warn that it is important that documentary analysis "is not limited to what is explicit in the material, but seeks to go deeper, revealing implicit messages, contradictory dimensions and themes that are systematically silenced." (LÜDKE and ANDRÉ, 1986, p.48). 
The documents were examined in search of information that could characterize student participation in school management actions, detecting the student's involvement, their forms of participation (direct or representative), among other aspects that contributed to the understanding of student participation dynamics and its content.

\section{DEMOCRATIC MANAGEMENT, YOUTH AND UPPER SECONDARY SCHOOL}

Democratic management is the object of struggle to progressive segments of the education area. This idea was incorporated into the Federal Constitution of 1988 as a principle of public education (Brazilian Federal Constitution, of 1988, Art. 206, VI), and reinforced in the National Educational Guidelines and Framework Law - LDBEN 9,394 of 1996 (Art. 3, VIII; Art. 14, I and II) likewise.

The National Education Plan, approved by Law 13.005 of 2014, includes "promoting the principle of democratic management of public education" as one of its guidelines (Art. 2, VI). Goal number 19 focuses on: "Ensuring conditions, within 2 (two) years, for the effective management of democratic education, associated to merit and performance technical criteria, as well as the participation of the school community". In the viewpoint of Marques (2014) the word choice in goal 19 is inconsistent because it merges democratic management related lexicon to meritocracy elements.

This goal is followed by strategies that address different issues considered fundamental for the effectiveness of democratic management, of which the strategies number 19.4, 19.5 and 19.6 can be highlighted as those that deal more directly with the participation of students in school management. These strategies address, respectively: encouraging the creation and strengthening of student unions and their articulation with school councils; encouraging the constitution and strengthening of school councils, training counselors and guaranteeing the autonomous functioning conditions of this collegiate body; and encouraging the participation of students in the formulation of pedagogic political projects, school curricula, school management plans and school regulations.

In addition to the achievements in the legal scope, the results of struggles happening both in the practical actions field and in the defending of ideas area are also reflected on the scientific production concerning education management, which has been the subject of countless studies in the field of education, as shown by the state of the art in Martins and Silva's (2011) research. 
The authors cataloged the scientific productions on the matter of management, autonomy and the functioning of collegiate bodies in basic education schools, between the years 2000 and 2008. This investigation resulted in 753 research papers, arranged under the following categories: 1) Spaces and mechanisms for intra-school participation; 2) In-school relationships and practices; 3 ) Governmental and non-governmental policies, programs, and projects; 4) Theories and Concepts.

Martins and Silva (2011) emphasize the poor amount of studies on the institutionalized representation and participation instances in schools, as well as on their impacts on management. The authors noted that from the total number of examined works "only 85 focused on the analysis of collegiate bodies, legitimate channels of representation, participation and negotiation spaces that, presumably, should constitute the main mechanism of participatory educational management." (MARTINS; SILVA, 2011, p. 14).

Building democratic management in public schools requires a type of work organization that is suitable to collective action and to the existence of institutional instruments and mechanisms that guarantee the participation of different segments of the school and the local community in management and decision-making processes over different issues of interest to the school.

The Pedagogic Political Project - PPP and the collegiate bodies, especially school councils, are important means for implementing the democratic management principle if created and conducted according to the assumptions of this management concept. Although the PPP and the school council are, in theory, part of the democratic management theoretical framework, the actual situation observed in many schools reflects a discrepancy on the meaning these instruments assume. Detached from the political sense that coins them within the scope of democratic management creation, they appear as mere technical tools.

The National Educational Guidelines and Framework Law establishes (LDBEN of 1996) the participation of different school and local community segments in the creation of the PPP and in School Council as a democratic management principle. Education systems are responsible for defining the rules for the democratic management of public schools in basic education, by taking peculiarities into account under the following principles: "participation of education professionals in the elaboration of the school's pedagogical project; participation of school and local communities in school councils or equivalent ". (LDBEN, Art. 14, I and II).

It is worth mentioning that the mere introduction of a new matter in the legislation does not have enough strength to promote changes in the daily life of education systems, especially in 
contexts with a strong record of despotism and personalism, such as Brazilian public education systems. According to Pires and Mororó (2018),

Management can become more democratic even when it is not law determined. When more participatory and collective ways of thinking about the school's directions and of reflecting on its educational intent and its objectives are established, it also creates possibility for learning the democratic mechanisms of participation and decision making which are sustained on another mindset in the way of managing the school and conducting the pedagogical work developed there.

Thus, the act of reinforcing the importance of assessing to what extent the principle established since the Federal Constitution of 1988 has resonated in new structures and demonstrated support for new management practices.

Democratic management mainly involves rethinking the school's power structure, aiming at its socialization. The socialization of power promotes the practice of collective participation, which attenuates individualism; reciprocity, which eliminates exploitation; solidarity, which overcomes oppression; autonomy, which eliminates the dependence on intermediary entities that create educational policies of which the school is simply an executor. (VEIGA, 2013, p. 18).

In this perspective, the goal of a Pedagogic Political Project goes far beyond a "formal school rearrangement. Instead, it focuses on quality in the whole experienced process". (VEIGA, 2013, p. 15). The school council, a place where different group segments have representative participation, is the mainstay of the PPP and the highest level for its approval (VEIGA, 2007).

The participation of different segments must not only figure as a value, but it also needs to present material ground for its practical development. Araújo (2009, p. 258) highlights the main channels of participation regarding students.

Among the political-pedagogical channels of participation that should be expanded and guaranteed to students, the following stand out: student union; school council; open and participatory class council; classroom teaching contract; school general assembly and school pedagogical and political project. When the institution's characteristics are respected, these mechanisms work as important spaces for decision making, discussion, and deliberation on the issues that permeate the school routine.

Discussing student participation in upper secondary school level demands contemplating the status of youth in Brazil as well. Studies in the youth field argue that a young person should be treated as a subject of rights and youth should be a stage in life with a meaning of its own, not only 
as a transition phase (ARROYO, 2014). Research indicates that young people resent not being heard, even in youth-related socially accredited institutions such as schools.

In Brazil, the development of a public agenda around youth issues dates to the late 1980s. The first youth-related public policies considered this period and the lack of dialogue with an actiondemanding audience as social problems. (SPOSITO; CARRANO, 2003). Over the years, the development of a certain sensitivity to the understanding of young people as a subject of rights was noticed. Within this new perspective, the process of formulating and evaluating policies saw greater acceptance for dialogue. (RIBEIRO; MACÊDO, 2018).

This tenuous opening of the public agenda to young subject's participation did not radically modify youth public policies arrangement. Public policies of a broader nature that reach young people, such as educational policy, are still marked by the lack of spaces and/or strategies for listening and participation both in the formulation and in the implementation and evaluation methodologies.

At school, this is reflected in teaching methodologies that range from excessive guidance to punctual student participation. The first perspective restricts the student's action to practical responses to school rules and tasks. The second is characterized by fragmented actions of student involvement in the organization or development of actions. Alternatively, the second perspective is characterized by the opening of formal spaces of participation, such as seats in collegiate bodies, however without favoring training processes for this participation.

Since the 1990s, accelerated growth in the upper secondary education demand has pushed public authorities to an expansion of the network of educational institutions. Every state had to enlarge their network of schools, considering they have priority for upper secondary education provision, attributed to these federated entities by LDBEN of 1996. Today, state schools account for $84.7 \%$ of enrollments in this educational level (INEP, 2019).

In the "quantity versus quality versus diversity" equation, it is still necessary to investigate the real operating conditions of Brazilian upper secondary schools, especially considering the existing suspension of public education expenses, which was instated through the Constitutional Amendment 95 of 2016. In Mariano's understanding (2019), such a measure represents Brazil's return to a state of economic exception and disastrous capitalism.

To Dayrell and Carrano (2014) it is vital for a school to know its students and consider the multiple dimensions that constitute their youth situations. According to the authors, such an 
understanding will assist in reorienting the ways young students are seen and treated, making upper secondary school a more pleasant place to be.

When a school seeks to understand the diversity of styles, tastes, languages, and projects of young people, respecting and aiming to adapt pedagogical and curricular proposals to the profile of its audience, everyone involved wins. Being in an environment that encourages autonomy and strives for dialogue and freedom, not only is more pleasant but also generates a sense of belonging as it inspires students to care for their school.

Several young people-related prejudices disseminated at schools repeat recurring common opinions in which teenagers are seen as individuals who are rebels, disinterested, contrary to norms and obligations, among other things. With such mindset schools risk not discovering young people with great potential, who could contribute to the school environment and in their community.

Upper secondary schools become vital spaces to make young people recognize themselves as subjects, considering these places deal with individuals at a stage in their lives defined by their need for self-assertiveness, when seeking new life experiences and demonstrating their skills and potential to the society around them.

\section{THE SITUATION OF STUDENT PARTICIPATION IN THE AMAZONAS SCHOOL}

The study's empirical phase was carried out in a state school located in Manaus, capital of the State of Amazonas, Brazil. This City, which concentrates more than half of the State's population, is riddled with contradictions on the distribution of public services and urban infrastructure. The Amazonas School is located in a privileged area due to the infrastructure apparatus it brings together, contrary to many locations where state public schools are distributed.

Amazonas School is configured as a small unit in terms of physical structure and number of students (initial enrollment of 550 students in 2016), considering the current Amazonas state educational network parameters. It exclusively focuses on upper secondary education during mornings and afternoons.

The school's General Rules and Regulations document is a perfect replica of the General Rules of the State Schools of Amazonas, established by Resolution No. 122 of the Amazonas State Education Council - CEE / AM, of November 30, 2010. Among other objectives, the document establishes the following democratic management related items: 
To define forms of democratic management for the schools integrating the State Education Network according to their peculiarities, based on the following principles: a) participation of education professionals in the school's Pedagogic Political Project development; b) participation of both school and the local community in an equivalent School Council. (AMAZONAS / SEDUC, 2010, Art. $6^{\circ}$, V)

Concerning the responsibilities of the different federated entities in school education provision, LDBEN of 1996 establishes that it their task, "to ensure elementary education and to offer, with priority, upper secondary education to all who demand it [...]" (Art. 10, VI). In Amazonas, the State has a significant role in the provision of elementary education. Thus, the General Regulation under analysis presents provisions aimed at all teaching units in the state network. In order to keep the focus on the research objectives, the analysis of this document focused on aspects that refer to the school management and upper secondary school axis.

Abiding by the national rule, the General Regiment of State Schools of Amazonas establishes a minimum three-year duration for upper secondary education. It also reinforces the aims of this educational level, which are: consolidation and deepening of knowledge acquired during elementary school and enabling of further education; preparation for professional life and citizenship, to continue learning and flexibly adapting to occupation or improvement conditions; improvement of ethical training and developing intellectual autonomy and critical thinking, making it possible to understand the scientific-technological foundations of production processes, relating theory to practice. (AMAZONAS. SEDUC, 2010)

A proper fulfillment of such purposes requires an environment that fosters participation and is guided by democratic society values, so that the school satisfies its role in ethical training, in addition to bringing students closer to the knowledge produced about different languages and technologies.

When addressing pedagogical practice methods available to teachers' choice, the School Rules and Regulations reveals an idea of student which refers to the hypothetical universe of a school that fosters democratic participation. The methods include dialogue, interpretation and critique, freedom of speech, respect for the student's culture and social practices, encouragement to the practice of citizenship, participation, leadership, personal growth and promotion of the students and their co-responsibility in knowledge acquisition, cooperation amidst parents, technicians and other members of the school system, et cetera. (AMAZONAS, 2010).

As for the assessment of school performance, article 61, paragraph 6 of the Rules and Regulation document, states that the development of reasoning, critical sense and the abilities to 
relate concepts and facts, associating cause and effect, analyzing and making decisions, are criteria for evaluating the teaching-learning process results.

Regarding the school community involvement in management processes, the General Regulation provides for the importance of such participation, when it states schools' obligation of maintaining a parent, teacher and community association as a minimum operating requirement, and institutes others school support bodies (AMAZONAS, 2010, Art. 15, IX). Among the ones defined as supporting entities in the analyzed Regulation, it is important to highlight the Student Union and the School Council for this research's objectives.

As provided in the Rules, "The School Council is a deliberative, consultative, supervisory and mobilizing collegiate body" (AMAZONAS, 2010, Art.102, p. 32). It consists of the following representative members: President (School Principal), Teachers and Education Specialists Association, Parent Teacher and Community Association, Student Union and Organized Social Movements, as determined (AMAZONAS, 2010).

Some goals that must be assured by the Internal School Regulation. Among these, the purpose of "ensuring the principle of plurality and democratic participation in the School's deliberative plan" stands out (AMAZONAS, 2010, Article 102, III).

The Regulation establishes the student body's rights to "speak and vote in the administrative decisions of the School Institution; access the internal school facilities, except for places the school manager considers restricted; participate in school collegiate bodies "(AMAZONAS, 2010, Article 250, II, IV, VIII).

Further Regulation analysis shows that, despite some inconsistencies and weaknesses found in the referred document's content, the State of Amazonas Education Network has reinforced democratic management as a public education principle, also establishing assumptions for student participation.

The General Rules of State Network Schools, in which community participation is foreseen, encompass curricula standards, teachers' pedagogical practices, student evaluation methods, autonomy for schools when creating their internal normative act, student's rights and the creation of school support organizations.

The school's General Rules and regulations endorse democratic management. Yet there are some obstacles to its implementation in public schools, such as nomination as a way of filling the position of school principal and the delegation of school management to the Schools' functional 
bodies (board, secretary, pedagogical and administrative areas), which do not bind the school council, nor the representation of students and other segments.

The occupation of the school principal position follows the national trend found by Souza (2019, 286), who claims that "the partial victory is not using more democratic models such as elections and emphasizing the technical aspect of the political (and electoral) association of the school leader to the current government."

In the sequence of this research's development, the following school documents were analyzed: Pedagogic and Political Project (2015), Class Representatives Reports, Student Representative Class Assignments, School Board Election Book 2009 to 2018, Minutes Book of Pedagogical Meetings from 2014 to 2015 and other documents attached to the PPP.

In the PPP, the elements that indicate student participation are generally stated without an explanation of the students' involvement in the elaboration process or suggestions for their engagement in the project's implementation and evaluation stages. In the opening elements of the PPP, the creation form attests that the student representation was present in the project's development process, alongside with other segments of the school and local community representatives. In the document's specific objectives and the justification section, the commitment to democratic management and the participation of all members of the school community is also affirmed and it is supported by a part of the justification sector. (AMAZONAS, 2015). (AMAZONAS, 2015).

In Amazonas School's Pedagogic Political Project an annex entitled "Standard Teacher" can be found. Its objective is to reward the teacher that displays the best behavior daily. Attendance, punctuality, and meeting of deadlines are its judging criteria. Monitoring and evaluation are carried out by the management team, but it is believed that it would be interesting to enable students' participation in this project.

In general, not envisioning the student's contribution to the evaluation process of teachers or even of the institution is an action that reflects disbelief about the youth's participation capacity. It is astonishing that even in an educational institution, it seems easier to exclude teenagers from participation rather than enabling them to it. Nardi (2015), highlights the importance of learning how to participate and reinforces the procedural condition of engagement, as "the path made while walking" (NARDI, 2015, p. 658).

The school's PPP presents an Activity Calendar for the year 2015. In this document, it is observed that student participation is effective in two types of activity: festivities and the delivery 
of monthly reports from class representatives. On festive dates and events such as the school anniversary, student's day, teacher's day and science fair, student participation is restricted to the cultural presentations of dances, theater, music, etc. There is no student involvement in the event's management.

The 2014 and 2015 Management Plans were also examined. The 2014 Management Plan has 11 goals. For each goal, action challenges, objectives, strategies, leader, deadlines status (whether it has been reached or is in progress) are presented. For this study, the challenges and responsible people described in the 2014 Management Plan are significant for analysis.

The student segment is not expected to participate in any of the management plan challenges. The involvement of the School Council or other collegiate bodies that could count on the representation of the different segments is not even foreseen. This data unveils a vulnerability in the understanding of the support that the School Council could and should provide to school management.

By excluding students from responsibility for these goals, the school misses the opportunity to enable the participation of a fundamental segment in the alignment between pedagogical practices and the needs of the school. Students could, for example, present the main obstacles encountered in admission exams preparation or suggest the school to enable more significant participation of parents and guardians. A School Council that effectively fulfilled its role could be a space for students to express themselves about these different aspects that make up the school reality.

The 2015 Management plan is also silent as for the School Council participation in implementing the established goals. In the 2015 version, the Management Plan includes the involvement of Parent Teachers and Community Association (APMC) among those responsible, under the representation of its presidency.

The dialogue with the school's student body would assist the mediation and resolution of some problems faced by the institution. One can think, for example, on young people's contribution to solving the school dropout issue, which is one of the challenges listed in the Management Plan 2015. Thus, relationships, coexistence, and experiences that young people share in the school environment makes them able to understand the reasons why their classmates leave school from a perspective that is not tangible to teachers and other professionals.

The choice of class presidents is a consolidated practice at school. Monthly class representatives deliver reports for evaluating the management team. The Report is presented in a 
standard form, made available by the school. It is a survey with questions that concern discipline, teacher-student relationships, interpersonal relationships, physical space, materials, and equipment, etc. The assignments and the class president profile are also provided for in the Form.

It is noteworthy that Amazonas School builds its work structure with the collaboration of class presidents, which demonstrates a strengthening in the relationship and dialogue between the school manager and the student body. Apparently, the delivery of monthly reports by the class presidents makes it possible to monitor classroom routine, teachers- student interaction and other events.

Through the work carried out with the class presidents, the school also contributes to the personal development of the students involved in this work, as it favors the acquisition of responsibilities in a job that involves the common good. This generates significant learning experiences for life in society, creating in these students a sense of feeling of belonging to their school.

A lack of records on the School Council performance was verified. According to the Elections Minute Book (from 2009 to 2018), the Council was instated in 2009, having gone through three formations until 2014. From 2009 on, the school's commitment to the implementation and permanence of this entity in the institution was observed, as well as the notable participation of the school community in the election processes of council representatives.

There are some records of School Council meetings. Nevertheless, the student segment Council representatives did not attend these gathering.

The school maintains a habit of hosting pedagogical meetings, many of which directed at student affairs. These meetings records demonstrate a dialogue between the institution's management and students. Students are mostly represented by their class presidents during these gatherings. On these occasions, different matters are addressed, such as students' role in organizing festive events, the presentation of participatory management processes, among other subjects.

Data collected at Amazonas School reveal the institution's care in passing on information about its functioning to students, as well as the strong presence of class presidents in school meetings. It is evidenced that the School has projects and activities in which student's leadership could be triggered.

\section{FINAL REMARKS}


This research reinforces the relevance of educational management studies in the context of student participation, considering that the circumstances of Brazilian educational institutions reveal many challenges when it comes to materializing the principle of democratic management in public education. Although the creation and strengthening of institutional spaces is not the only possibility to encourage student participation in decision-making, it proves to be one of these important challenges.

Amazonas School data related analysis reveals that there are few and fragile forms of student participation in educational management foreseen in the pedagogic political project. It is also observed that some actions in which student participation occurs are not envisioned or highlighted in the PPP.

Amazonas School's General Regulations and its Pedagogic Political Project reinforce the principle of democratic management of public education, highlighting the importance of student participation in collegiate bodies and of a critical and citizen formation, articulated with the principles that govern a democratic society.

Despite these highlights on the importance of democratic management, the documents and practices experienced at school lack better defined proposals, envisioning ways to reach the valuable constitutional principle of public education democratic management. As a necessary development to achieve this goal, the school should insist and invest in means of strengthening student participation in meetings, collegiate bodies activities and also in the process of discussing and evaluating the Pedagogic Political Project, in addition to encouraging its organization in the Student Union.

The records made available by Amazonas School to this study reveal an incipient student participation in the drafting of the Pedagogic Political Project, but a strong relationship with students in cultural activities, class representation and dialogue on different topics of interest to the School. These results indicate a certain mismatch between the expected engagement in the PPP, the School Rules and Regulations and the actual student participation practices registered in schools. However, it is also noticeable that the observed potentials can be explored in order to take student participation at Amazonas School to another level.

The realities of public school institutions in the State of Amazonas are manifold. Therefore, studying the existence and functioning of collegiate bodies that promote student participation in more teaching intuitions and listening to secondary school students aiming to discuss possible paths for their participation in school management would be a good way to extend this research. 


\section{REFERENCES}

AMAZONAS. SECRETARIA DE EDUCAÇÃO E QUALIDADE DO ENSINO DO ESTADO DO AMAZONAS. Regimento Geral das Escolas Estaduais do Amazonas. Manaus: CEE, 2010.

AMAZONAS. Projeto Político-Pedagógico. Manaus: SEDUC-AM, 2015.

ARROYO, Miguel Gonzáles. Repensar o Ensino Médio: por que? In: DAYRELL, Juarez Tarcísio; CARRANO, Paulo, Carrano; MAIA, Carla Linhares (orgs). Juventude e Ensino Médio: sujeitos e currículos em diálogo. Belo Horizonte: Editora da Universidade Federal de Minas Gerais, 2014. p. 53-73.

ARAÚJO, Adilson César de. A gestão democrática e os canais de participação dos estudantes. Retratos da Escola, Brasília, v. 3, n. 4, p. 253-266, jan./jun. 2009. Disponível em: http://www.esforce.org.br/index.php/semestral. Acesso em 10 de abr. 2015. BRASIL. Constituição da República Federativa do Brasil - 1988. Disponível em: http://www.planalto.gov.br/ccivil 03/constituicao/constituicaocompilado.htm. Acesso em 08 abr. 2015.

BRASIL. Lei n. 9.394, de 20 de dezembro de 1996, Lei de Diretrizes e Bases da Educação Nacional - LDBEN. Disponível em: http://www.planalto.gov.br/ccivil_03/leis/19394.htm. Acesso em 08 de abr. 2015.

BRASIL. Lei n. 13.005, de 25 de junho de 2014, Aprova o Plano Nacional de Educação - PNE e dá outras providências. Disponível em: http://www.planalto.gov.br/ccivil_03/_ato20112014/2014/lei/l13005.htm Acesso em: 16 dez. 2015.

DAYRELL, Juarez Tarcísio. A escola "faz" as juventudes? Reflexões em torno da socialização juvenil. Educação \& Sociedade, Campinas, vol. 28, n. 100 - Especial, p. 1105-1128, out. 2007. Disponível em: http://www.scielo.br/pdf/es/v28n100/a2228100. Acesso em: 20 dez 2019.

DAYRELL, Juarez; CARRANO, Paulo. Juventude e Ensino Médio: quem é este aluno que chega à escola. In: DAYRELL; CARRANO; MAIA (orgs). Juventude e Ensino Médio: sujeitos e currículos em diálogo. Belo Horizonte: Editora da Universidade Federal de Minas

Gerais, 2014. p. 101-134.

INSTITUTO NACIONAL DE ESTUDOS E PESQUISAS EDUCACIONAIS ANÍSIO TEIXEIRA - INEP. Resumo Técnico: Censo da Educação Básica 2018, Brasília: Instituto Nacional de Estudos e Pesquisas Educacionais Anísio Teixeira, 2019. 66 p.

LÜDKE, Menga; ANDRÉ, Marli. - Pesquisa em educação: abordagens qualitativas. São Paulo: EPU, 1986.

MARIANO, Cynara Monteiro. Emenda constitucional 95/2016 e o teto dos gastos públicos: Brasil de volta ao estado de exceção econômico e ao capitalismo do desastre. Revista Investigações 
Constitucionais. Curitiba, vol.4 n.1, p. 259-281, jan./abr. 2017. Disponível em:

http://www.scielo.br/scielo.php?script=sci arttext \&pid=S2359-

56392017000100259\&lng=en\&nrm=iso\&tlng=pt. Acesso em: 19 dez. 2019.

MARQUES, Luciana Rosa. Gestão democrática da educação: os projetos em disputa. Revista Retratos da Escola, Brasília, v. 8, n. 15, p. 463-471, jul./dez. 2014. Disponível em:

http://www.esforce.org.br/index.php/semestral/article/view/453/584. Acesso em: 28 jan. 2016.

MARTINS, Ângela Maria; SILVA, Vandré Gomes. Estado da arte: gestão, autonomia da escola e órgãos colegiados (2000/2008). Cadernos de Pesquisa. v. 41, n. 142, p. 228-245. jan/abr, 2011. Disponível em: http://www.scielo.br/scielo.php?script=sci arttext\&pid=S010015742011000200017. Acesso em: 25 jan. 2017.

MARTINS, Francisco André Silva; DAYRELL, Juarez Tarcísio. Juventude e Participação: o grêmio estudantil como espaço educativo. Educação \& Realidade, Porto Alegre, v. 38, n. 4, p. 1267-1282, out./dez. 2013. ISSN 2175-6236. DOI 10.1590/S2175-62362013000400014. Disponível em: http://www.scielo.br/scielo.php?script=sci arttext\&pid=S217562362013000400014\&lng=en\&nrm=iso. Acesso em: 20 dez. 2019.

MINAYO, Maria Cecília de Souza. Ciência, Técnica e Arte: o desafio da pesquisa social. In: MINAYO, M. C. S (org). Pesquisa Social: teoria, método e criatividade. 23. ed. Petrópolis/RJ: Vozes, 1994.

NARDI, Elton Luiz. Itinerários da participação na gestão de escolas públicas de educação básica. RBPAE - v. 31, n. 3, p. 649 - 666 set./dez. 2015. Disponível em:

https://seer.ufrgs.br/rbpae/article/view/59089. Acesso em: 01 set. 2019.

PINHEIRO, Maria das Graças Sá Peixoto; CALDAS, Edla Cristina Rodrigues. Políticas Públicas e Gestão Escolar: a Participação da Comunidade em Escolas do Ensino Fundamental - Zona Leste de Manaus. In: XXIV Simpósio Brasileiro e III Congresso Interamericano de Política e Administração da Educação, 2009, Vitória. Cadernos ANPAE, 2009.

PIRES, Ennia Débora Passos Braga; MORORÓ, Leila Pio. O papel do projeto pedagógico escolar na política educacional: entre o legal e o instituível. Revista Tempos e Espaços em Educação. São Cristóvão, Sergipe, Brasil, v. 11, n. 01, Edição Especial, p. 335-350, dezembro, 2018. ISSN 23581425 DOI 10.20952/revtee.v11i01.9535 Disponível em:

https://seer.ufs.br/index.php/revtee/article/view/9535. Acesso em: 05 jan 2020.

RIBEIRO, Eliane; MACEDO, Severine. Notas sobre políticas públicas de juventude no Brasil: conquistas e desafios. Rev. Cien. Soc. vol.31 n.42, p. 107-126. Montevideo, jun. 2018. ISSN 16884981. DOI 10.26489/rvs.v31i42.5 Disponível em:

http://www.scielo.edu.uy/scielo.php?script=sci arttext\&pid=S079755382018000100107\&lng=es\&nrm=iso. Acesso em: 12 dez 2019.

SOUZA, Angêlo Ricardo de. As condições de democratização da escola pública brasileira. Ensaio: aval. pol. públ. Educ., Rio de Janeiro, v. 27, n. 103, p. 271-290, abr./jun. 2019. ISSN 0104-4036. DOI 10.1590/s0104-40362018002601470. Disponível em:

http://www.scielo.br/scielo.php?script=sci abstract\&pid=S0104-

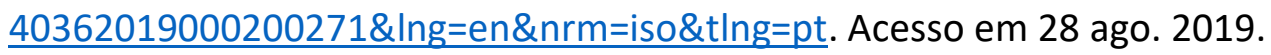


SPOSITO, Marília Pontes. Educação, Gestão Democrática e Participação Popular. In: BASTOS, João Baptista (org). Gestão Democrática. 2. ed. Rio de Janeiro: DP\&A, 2001.

SPOSITO, Marília Pontes; CARRANO, Paulo César Rodrigues. Juventude e políticas públicas no Brasil. Revista Brasileira de Educação, N 24, Set /Out /Nov /Dez 2003. p. 16-39. ISSN 1809-449X DOI 10.1590/S1413-24782003000300003. Disponível em:

http://www.scielo.br/scielo.php?script=sci arttext\&pid=S1413$24782003000300003 \&$ Ing=en\&nrm=iso. Acesso em 24 jan. 2020.

VEIGA, IIma Passos Alencastro. Projeto Político-Pedagógico da Escola: uma construção coletiva. In: VEIGA, Ilma Passos Alencastro (org.). Projeto Político-Pedagógico da Escola: uma construção possível. 29 ed. Campinas/SP: Papirus, 2013.

VEIGA, IIma Passos Alencastro. Conselho Escolar e Projeto Político-Pedagógico. In: VEIGA, Ilma Passos Alencastro. (org.). Quem sabe faz a hora de construir o Projeto Político-Pedagógico. Campinas/SP: Papirus, 2007.

\section{AUTHOR'S BIOGRAPHIES}

Nádia Maciel Falcão has a PhD in Education from Fluminense Federal University (UFF) and a master's degree in Education from the Education Graduate Program at the Federal University of Amazonas. She is a member of the Education, cultures and Amazonian challenges Research Group and a professor at the Federal University of Amazonas. E-mail: nadiafalcao@ufam.edu.br ORCID: https://orcid.org/0000-0002-3196-0341

Sara dos Santos da Silva has an undergraduate degree in Pedagogy from the Federal University of Amazonas (UFAM). She is a member of the Education, cultures and Amazonian challenges research group and a teacher at Manaus' Municipal Office of Education. Email: sarinha1993-2012@hotmail.com ORCID: https://orcid.org/0000-0001-6841-6430 